\title{
ANOMALOUS ANISOTROPIC MAGNETORESISTANCE AND MAGNETIZATION IN $\mathrm{Mn}_{3.69} \mathrm{Bi}_{95.69} \mathrm{Fe}_{0.62}$
}

\author{
A.V. Terekhov ${ }^{1,2}$, A.L. Solovjov ${ }^{1,2}$, A.I. Prokhvatilov ${ }^{1}$, V.V. Meleshko ${ }^{1}$, I.V. Zolochevskii ${ }^{1}$, \\ J. Cwik', A. Los', A.D. Shevchenko ${ }^{3}$, O.M. Ivasishin ${ }^{3}$, Z.D. Kovalyuk ${ }^{4}$
}

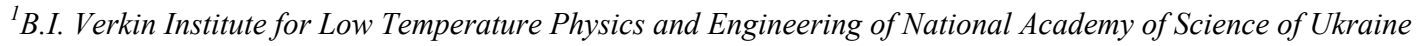
47 Nauky ave., 61103 Kharkov, Ukraine

${ }^{2}$ W. Trzebiatowski Institute for Low Temperatures \& Structure Research PAS

2 Okolna str., Wroclaw, Box 1410, 50-950, Poland

${ }^{3}$ G.V. Kurdyumov Institute for Metal Physics of National Academy of Sciences of Ukraine 36 Academician Vernadsky Blvd, Kyiv, UA-03142, Ukraine

${ }^{4}$ I.M. Frantsevich Institute for Problems of Materials Science. Chernivtsi Branch of National Academy of Sciences of Ukraine 5 I. Vil'dy str., Chernivtsi, 58001, Ukraine e-mail: terekhov.andrii@gmail.com

Received 13 October, 2017

It was found that the $\mathrm{Mn}_{3.69} \mathrm{Bi}_{95.69} \mathrm{Fe}_{0.62}$ consists of two phases, namely of a bismuth matrix and $\alpha \mathrm{BiMn}$ inclusions. It is shown that the samples have a crystalline texture. Independently on the applied field orientation, maximum on the temperature dependence of magnetization is detected at $T_{\max } \approx 85 \mathrm{~K}$, which is associated with the reorientation transition of the magnetic moments of Mn for $\alpha \mathrm{BiMn}$ phase. In turn, the electrical resistivity $\rho(T)$ also demonstrates maximum at $T_{\max } \approx 58 \mathrm{~K}$ in a magnetic field of $800 \mathrm{kA} / \mathrm{m}$ when $\boldsymbol{H} \perp \boldsymbol{I}$. It is established that the maximum of $\rho(T)$ increases and is shifted toward higher temperature $T_{\max } \approx 94 \mathrm{~K}$ when field increasing up to $2400 \mathrm{kA} / \mathrm{m}$. At the same time no clear maximum on $\rho(T)$ is observed for $\boldsymbol{H} \| \boldsymbol{I}$. It is shown that the relative magnetoresistance, $\Delta \rho / \rho_{0}$, is increased both with decreasing temperature and with increase of the magnetic field. The measured enhancement reaches $\Delta \rho / \rho_{0} \approx 250 \%$ for $\boldsymbol{H} \| \boldsymbol{I}$ and $\Delta \rho / \rho_{0} \approx 2400 \%$ for $\boldsymbol{H} \perp \boldsymbol{I}$ in magnetic field of $2400 \mathrm{kA} / \mathrm{m}$. Thus, the strong anisotropy of $\rho(T)$ and $\Delta \rho / \rho_{d}(T)$ is established both for $\boldsymbol{H} \perp \boldsymbol{I}$ and $\boldsymbol{H} \| \boldsymbol{I}$. Possible explanation of observed anomalous behavior of the temperature dependences of the electrical resistivity in magnetic fields has been proposed.

KEYWORDS: huge anisotropic magnetoresistance, reorientation transition, electron and hole Fermi surfaces, MnBi alloys, crystalline texture, bismuth

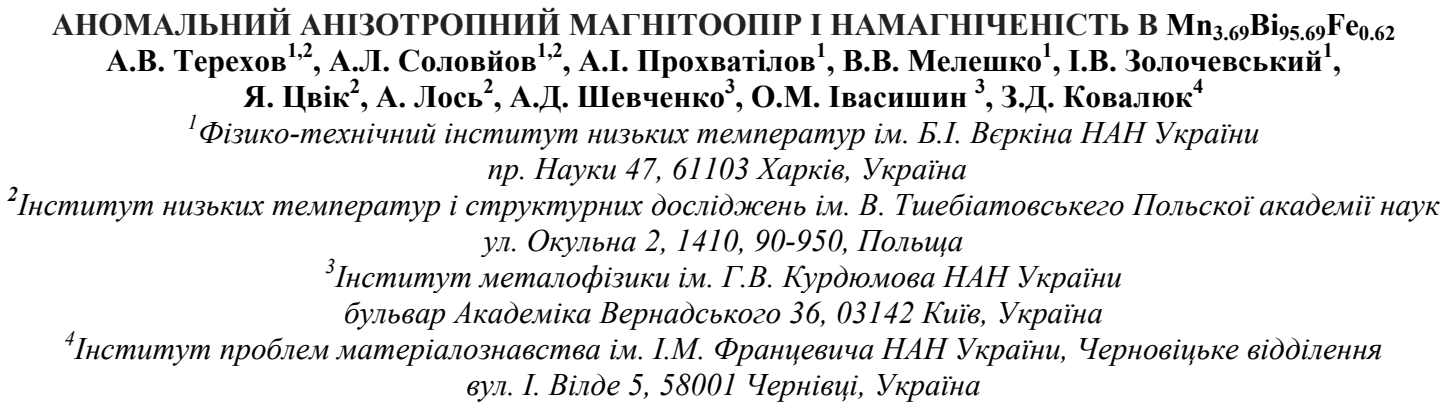

Було встановлено, що $\mathrm{Mn}_{3.69} \mathrm{Bi}_{95.69} \mathrm{Fe}_{0.62}$ складається 3 двох фаз - висмутової матриці та включень $\alpha \mathrm{BiMn}$. Показано, що зразки мають кристалічну текстуру. На температурній залежності намагніченості виявлено максимум при $T_{\max } \approx 85 \mathrm{~K}$, який не залежить від орієнтації прикладеного поля і пов'язан з переорієнтаційним переходом магнітних моментів Мn в фазі $\alpha \mathrm{BiMn}$. В свою чергу, електроопір також демонстрирує максимум при $T_{\max } \approx 58 \mathrm{~K}$ в магнитному полі 800 кА/м, коли $\boldsymbol{H} \perp \boldsymbol{I}$. Встановлено, що максимум на $\rho(T)$ зростає і зсувається до більш високої температури $T_{\max } \approx 94 \mathrm{~K}$, у міру збільшення поля до 2400 кА/м. У той же час максимум на $\rho(T)$ відсутній для $\boldsymbol{H} \| \boldsymbol{I}$. Показано, що відносний магнітоопір $\Delta \rho / \rho_{0}$ зростає 3 пониженням температури і зростанням магнітного поля. $\Delta \rho / \rho_{0} \approx 250 \%$ для $\boldsymbol{H} \| \boldsymbol{I}$ та $\Delta \rho / \rho_{0} \approx 2400 \%$ для $\boldsymbol{H} \perp \boldsymbol{I}$ в магнітному полі 2400 кА/м. Таким чином, встановлена сильна анізотропія та $\Delta \rho / \rho_{d}(T)$ для $\boldsymbol{H} \perp \boldsymbol{I}$ та $\boldsymbol{H} \| \boldsymbol{I}$. Запропоновано можливе пояснення спостережуваної аномальної поведінки температурної залежності електроопору в магнітному полі.

КЛЮЧОВІ СЛОВА: величезний анізотропний магнітоопір, переорієнтаційний перехід, електронна і діркова поверхні Фермі, MnBi сплави, кристалічна текстура, вісмут

АНОМАЛЬНОЕ АНИЗОТРОПНОЕ МАГНИТОСОПРОТИВЛЕНИЕ И НАМАГНИЧЕННОСТЬ В $\mathrm{Mn}_{3.69} \mathrm{Bi}_{95.69} \mathrm{Fe}_{0.62}$ А.В. Терехов ${ }^{1,2}$, А.Л. Соловьев ${ }^{1,2}$, А.И. Прохватилов ${ }^{1}$, В.В. Мелешко ${ }^{1}$, И.В. Золочевский ${ }^{1}$, Я. Цвик ${ }^{2}$, А. Лось ${ }^{2}$, А.Д. Шевченко ${ }^{3}$, О.М. Ивасишин ${ }^{3}$, З.Д. Ковалюк ${ }^{4}$

${ }^{I}$ Физико-технический институт низких температур им. Б.И. Веркина НАН Украины пр. Науки 47, 61103 Харьков, Украина

${ }^{2}$ Институт низких температур и структурных исследований им. В. Тшебиатовскего Польской академии наук ул. Окульна 2, 1410, 90-950, Польша 


\author{
${ }^{3}$ Институт металлофизики им. Г.В. Курдюмова НАН Украиньл \\ бульвар Академика Вернадского 36, 03142 Киев, Украина \\ ${ }^{4}$ Институт проблем материаловедения им. И.М. Францевича НАН Украины, Черновицкое отделение \\ ул. И. Вилде 5, 58001 Черновцьь, Украина
}

Было установлено, что $\mathrm{Mn}_{3.69} \mathrm{Bi}_{95.69} \mathrm{Fe}_{0.62}$ состоит из двух фаз - висмутовой матрицы и включений $\alpha$ ВіМп. Показано, что образцы имеют кристаллическую текстуру. На температурной зависимости намагниченности обнаружен максимум при $T_{\max } \approx 85 \mathrm{~K}$, который не зависит от ориентации приложенного поля и связан с переориентационным переходом магнитных моментов $\mathrm{Mn}$ в фазе $\alpha \mathrm{BiMn}$. В свою очередь, электросопротивление также демонстрирует максимум при $T_{\text {max }} \approx 58 \mathrm{~K}$ в магнитном поле $800 \mathrm{\kappa A} / \mathrm{M}$, когда $\boldsymbol{H} \perp \boldsymbol{I}$. Установлено, что максимум на $\rho(T)$ растет и сдвигается к более высокой температуре $T_{\text {max }} \approx 94 \mathrm{~K}$, по мере увеличения поля до 2400 кА/м. В то же время, максимум на $\rho(\mathrm{T})$ отсутствует для $\boldsymbol{H} \| \boldsymbol{I}$. Показано, что относительное магнитосопротивление $\Delta \rho / \rho_{0}$ растет с понижением температуры и ростом магнитного поля. $\Delta \rho / \rho_{0} \approx 250 \%$ для $\boldsymbol{H} \| \boldsymbol{I}$ и $\Delta \rho / \rho_{0} \approx 2400 \%$ для $\boldsymbol{H} \perp \boldsymbol{I}$ в магнитном поле 2400 кА/м. Таким образом, установлена сильная анизотропия $\rho(\mathrm{T})$ и $\Delta \rho / \rho_{d}(T)$ для $\boldsymbol{H} \perp \boldsymbol{I}$ и $\boldsymbol{H} \| \boldsymbol{I}$. Предложено возможное объяснение наблюдаемого аномального поведения температурной зависимости электросопротивления в магнитном поле.

КЛЮЧЕВЫЕ СЛОВА: огромное анизотропное магнитосопротивление, переориентационный переход, электронная и дырочная поверхности Ферми, MnBi сплавы, кристаллическая текстура, висмут

MnBi alloys occupy particular place among permanent magnets. First of all, this is due to the fact that the elements that make up these composites are quite inexpensive compared to magnets that are made of rare-earth materials. Secondly, Mn-Bi solid solutions have sufficiently large values of coercive force at room temperature, which increases with a further increase in temperature. The temperature of transition to the ferromagnetic state in $\mathrm{Mn}-\mathrm{Bi}$ solid solutions is quite high $T_{C} \approx 640 \mathrm{~K}$. It makes these materials rather attractive for their use as permanent magnets in hightemperature applications [1,2].

Despite a vast amount of works that are devoted to the study of the magnetic properties of MnBi alloys, the investigation of their electric transport was almost never carried out. For the first time we revealed the presence of a huge anisotropic magnetoresistance in $\mathrm{Mn}_{6} \mathrm{Bi}_{93.99} \mathrm{Fe}_{0.01}$ [3].

The primary aim of the paper was to clarify the relationship between the magnetic properties and the features of the temperature dependence of the electrical resistance in an external magnetic field in $\mathrm{Mn}_{3.69} \mathrm{Bi}_{95.69} \mathrm{Fe}_{0.62}$.

This paper presents results of investigation of the temperature dependences of the electrical resistivity and the magnetization of $\mathrm{Mn}_{3.69} \mathrm{Bi}_{95.69} \mathrm{Fe}_{0.62}$ in various magnetic fields.

\title{
SAMPLES AND MEASUREMENT TECHNIQUE
}

The samples were obtained by crystallization using the Bridgman method at a temperature of $630 \mathrm{~K}$ with a growth rate of $1,5 \mathrm{~mm} / \mathrm{h}$. The synthesis has been performed in a horizontal tube furnace of the SUOL type. The quartz tubes of 16-18 mm long evacuated to the pressure $P \sim 10^{-2} \mathrm{~Pa}$ were used as containers for the synthesis and growth. The preparation of single-crystal or coarse-grained textured samples was possible with this growing method. The final ingots were obtained in the form of cylinders. Rectangular samples of about $7 \times 2 \times 2 \mathrm{~mm}$ were cut out along of the base of cylinder (conditionally perpendicular to the $c$ axis) for the electrical resistance measurements.

Testing of the grown samples was carried out by X-ray analysis on a DRON-3 diffractometer in $\mathrm{CuK}_{\alpha}$ radiation $(\lambda=1,54178 \AA)$ at room temperature. Observation of the microstructure was done using a scanning electron microscope (SEM). A fully computerized setup on the bases of a physical properties measurement system (Quantum Design PPMS-9T) utilizing the four-point probe technique was used to perform the electrical resistance measurements with sufficient accuracy. Current and potential contacts were created by means of silver paste. Contact resistances below $1 \Omega$ were obtained. Resistivity was measured using alternating current $(I=30 \mathrm{~mA}, f=17 \mathrm{~Hz})$ flowing along the largest sample dimension. Measurements were performed in a wide temperature range $(300 \div 4.2) \mathrm{K}$ both without magnetic field and in magnetic field applied perpendicularly and parallel to the measuring current. Magnetic measurements were performed with the Quantum Design SQUID magnetometric system in a wide temperature range $(300 \div 4.2) \mathrm{K}$. The magnetic field was generated with superconducting solenoid powered by a DC source operating in a continuous regime.

\section{RESULTS AND DISCUSSION SEM studies}

The quantitative elemental composition of the alloy set using the SEM is the following: 95.69 at $\%$ Bi, 3.69 at $\%$ $\mathrm{Mn}$ and $0.62 \mathrm{at} \% \mathrm{Fe}$. Fig. 1 shows the microstructure of prepared BiMn alloy. Unfortunately, it is impossible to distinguish clearly the different phases. However, taking into account the phase diagram [4], it can be assumed that the main volume is occupied by $\mathrm{Bi}$, in the matrix of which there are areas of the $\alpha \mathrm{BiMn}$ phase.

\section{X-ray studies}

X-ray diffractograms of $\mathrm{Mn}_{3.69} \mathrm{Bi}_{95.69} \mathrm{Fe}_{0.62}$ alloy indicate the monophase and polycrystallinity of the sample. The polycrystal has hexagonal lattice with parameters $a=4,558 \AA, c=11,885 \AA, \beta=120^{\circ}$ which are slightly higher than for pure $\mathrm{Bi}(a=4,54 \AA, c=11,82 \AA)$. This allows us to say that the sample is a weak solution of $\mathrm{Mn}$ atoms in the $\mathrm{Bi}$ 
hexagonal lattice. The presence in the diffraction patterns of reflection (202), which is absent in pure bismuth [5], most likely indicates the presence of a small amount of the phase $\alpha \mathrm{BiMn}$. The possibility of this phase presence in this concentration range follows from the equilibrium phase diagram [4]. The texturing of the samples was verified by a parallel comparison of the X-ray diffraction patterns of a massive solid polycrystalline alloy and its powder. The X-ray diffraction patterns of the solid and ground samples are shown in Fig. 2.

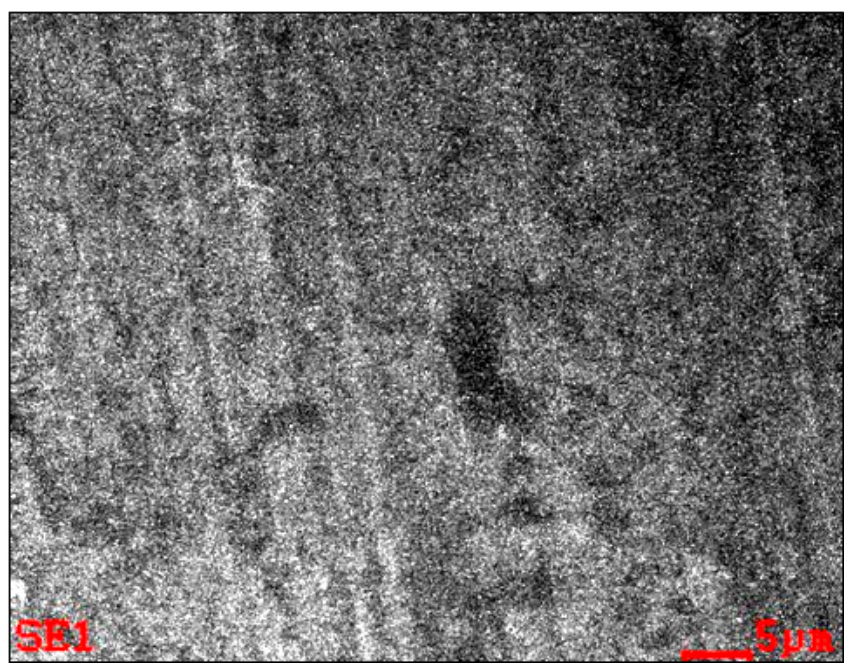

Fig.1. Microstructure of $\mathrm{Mn}_{3.69} \mathrm{Bi}_{95.69} \mathrm{Fe}_{0.62}$ alloy.

The X-ray diffraction patterns of solid and powder samples are qualitatively similar and they fairly well indicate the hexagonal structure of the system. Fairly close values of the hexagonal lattice parameters $a=4,558 \AA, c=11,885 \AA$, $\beta=120^{\circ}$ and $a=4.5647 \AA, c=11.893 \AA, \beta=120^{\circ}$ were obtained for the polycrystalline and powder samples, respectively. Integral intensities of most diffraction lines are 20 to $70 \%$ higher for the powder than for the massive sample. The intensity of the line (202) is almost 2.5 times higher for the powder than the corresponding reflection of the massive alloy. The higher intensity of scattering by the powder is partially due to the removal of the microstresses which exist in the massive sample. Anomalously large differences in the intensities of individual lines of powder and massive samples may indicate the presence of a growth texture in the polycrystalline sample.

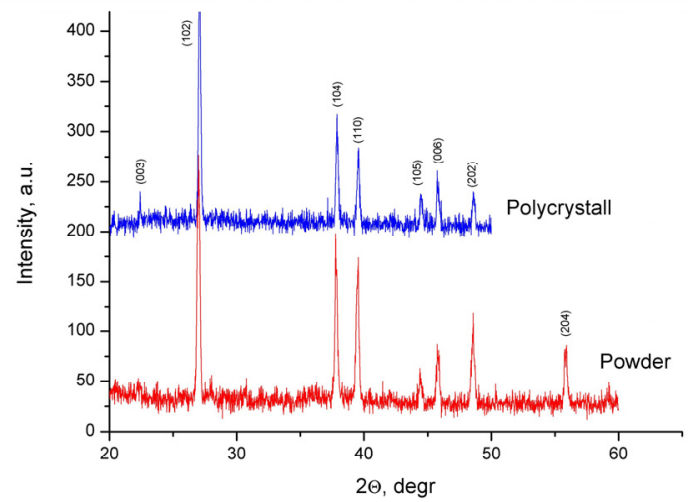

Fig.2. X-ray diffraction patterns of polycrystalline and powder samples of the $\mathrm{Mn}_{3.69} \mathrm{Bi}_{95.69} \mathrm{Fe}_{0.62}$ alloy Diffractograms were obtained at room temperature in $\mathrm{CuK} \alpha$ radiation

\section{Magnetization studies}

The temperature dependencies of magnetization $M(T)$ in the magnetic fields 320,800 and $2400 \mathrm{kA} / \mathrm{m}$ are shown in Fig. 3. Importantly, $M$ vs $T$ dependence measured at $320 \mathrm{kA} / \mathrm{m}$ have a maximum at $85 \mathrm{~K}$. Earlier, the authors of [6] investigated the magnetic properties of solid solutions with a larger content of $\alpha \mathrm{BiMn}$ phase than we and found a maximum on $M(T)$ at a temperature of $90 \mathrm{~K}$. They explained the presence of this anomaly by reorienting of the Mn magnetic moments. It is found that the $\mathrm{Mn}$ atom changes its spin direction from a perpendicular to a parallel orientation with respect to the $\mathrm{c}$ axis in the temperature range from 30 to $150 \mathrm{~K}$. We think that this explanation is also acceptable in our case.

Apparently, the reorientation transition of the magnetic moments of Mn disappears in fields above $2400 \mathrm{kA} / \mathrm{m}$. As a result, the $M(T)$ dependence in a field of $2400 \mathrm{kA} / \mathrm{m}$ approaches a typical ferromagnetic one. 
It is seen in the figure, that $M(T)$ dependencies measured in the directions $\boldsymbol{H} \| \boldsymbol{c}$ (open symbols) and $\boldsymbol{H} \perp \boldsymbol{c}$ (closed symbols) are the same. According to [2], $M$ vs $T$ dependencies measured in different directions for single crystals of BiMn are different. The similarity of the $M(T)$ curves observed in our case can be attributed to the polycrystallinity of our sample. The areas with the $\alpha \mathrm{BiMn}$ phase can be crystallographically disordered in the textured Bi matrix. Although the content of the $\alpha \mathrm{BiMn}$ phase is quantitatively lower $(<10 \%)$ in comparison with $\mathrm{Bi}$, its magnetic properties are believed to predominate over $\mathrm{Bi}$, which is a strong diamagnet [7].

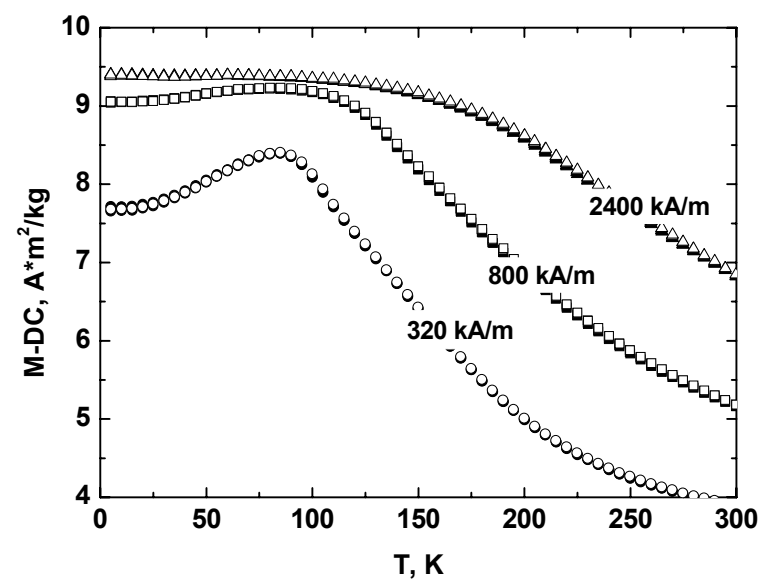

Fig. 3. $M(T)$ dependencies of $\mathrm{Mn}_{3.69} \mathrm{Bi}_{95.69} \mathrm{Fe}_{0.62}$ measured in two directions $(\bullet, \boldsymbol{\square}, \boldsymbol{\Delta}-\boldsymbol{H} \| \boldsymbol{c}$, and $\circ, \square, \Delta-\boldsymbol{H} \perp \boldsymbol{c})$ in magnetic fields $320 \mathrm{kA} / \mathrm{m}(\bullet, \circ), 800 \mathrm{kA} / \mathrm{m}(\mathbf{\bullet}, \square)$ and $2400 \mathrm{kA} / \mathrm{m}(\boldsymbol{\Lambda}, \Delta)$.

\section{Electrical resistivity studies}

Curves of $\rho(T)$ measured in the absence of magnetic field (symbols - $)$ ) and in magnetic fields of $800 \mathrm{kA} / \mathrm{m}$ (symbols - $\mathbf{-}, \square$ ) and $2400 \mathrm{kA} / \mathrm{m}$ (symbols - $\boldsymbol{\Delta}, \Delta$ ) in two directions $\boldsymbol{H} \| \boldsymbol{I}$ and $\boldsymbol{H} \perp \boldsymbol{I}$ are shown in figure 4 . The dependences of $\rho(T)$ measured in both directions in the absence of magnetic field behave similarly to those for pure bismuth [8-10] namely, with decreasing temperature, the resistivity decreases and there are no singularities on the curve. In Refs. [8, 10] it was shown that small additions of impurity atoms to bismuth may cause the appearance of anomalies on $\rho(T)$, such as maxima, or semiconductor dependence. In our samples it is not the case, suggesting conclusion that in the absence of magnetic field the main contribution to the conductivity is made by the bismuth phase.

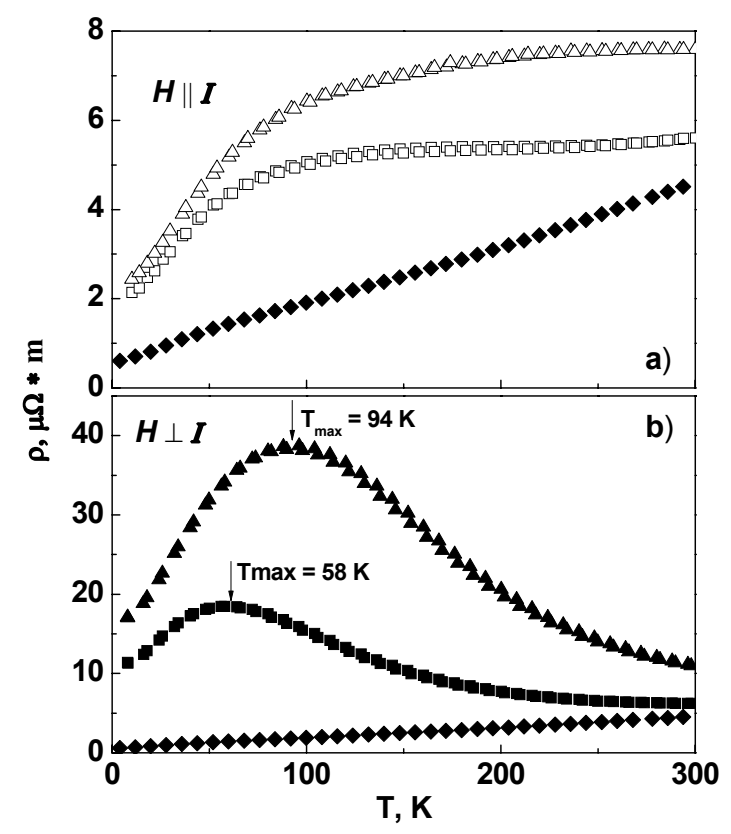

Fig. 4. $\rho(T)$ dependencies for $\mathrm{Mn}_{3.69} \mathrm{Bi}_{95.69} \mathrm{Fe}_{0.62}$ measured for two directions ( $\square, \Delta-\boldsymbol{H} \| \boldsymbol{I}$, and $\left.\boldsymbol{\varpi}, \boldsymbol{\Delta}-\boldsymbol{H} \perp \boldsymbol{I}\right)$ in magnetic fields 800 $\mathrm{kA} / \mathrm{m}(\boldsymbol{\square}, \square)$ and $2400 \mathrm{kA} / \mathrm{m}(\boldsymbol{\Lambda}, \Delta)$. The $\rho(T)$ dependences measured in zero magnetic field are denoted by $(\bullet)$. 
Switching on the magnetic field leads to a change in the form of the $\rho(T)$ dependences, and the magnitude of the electrical resistance increases substantially (Fig. 4). For $\boldsymbol{H} \| \boldsymbol{I}$ the electrical resistivity decreases with decreasing temperature (Fig.4a). The rate of the decrease noticeably increases below $100 \mathrm{~K}$. For $\boldsymbol{H} \perp \boldsymbol{I}$ the $\rho(T)$ dependencies have completely different form (Fig.4b). The electrical resistivity increases with decreasing temperature, and reaches a maximum at $T_{\max } \approx 58 \mathrm{~K}$ and $\approx 94 \mathrm{~K}$ in the fields of 800 and $2400 \mathrm{kA} / \mathrm{m}$, respectively. Then $\rho(T)$ decreases down to helium temperatures. Accordingly, $\rho_{\boldsymbol{H} \perp \boldsymbol{I}}(300 \mathrm{~K}) / \rho_{\boldsymbol{H} \| \boldsymbol{I}}(300 \mathrm{~K}) \approx 1.1$ and $\approx 1.4$ for fields of $800 \mathrm{kA} / \mathrm{m}$ and $2400 \mathrm{kA} / \mathrm{m}$, respectively, whereas $\rho_{\boldsymbol{H} \perp \boldsymbol{I}}(5 \mathrm{~K}) / \rho_{\boldsymbol{H} \| \boldsymbol{I}}(5 \mathrm{~K}) \approx 5.4$ and $\approx 7$ for the same fields values. These relationships indicate that the anisotropic properties of our samples increase with decreasing temperature.

The behavior of $\rho(T)$ in magnetic fields differs from that observed earlier in pure bismuth [11-13]. According to [11-13], the electrical resistivity in magnetic field increases with decreasing temperature down to helium temperatures. Revealed in our experiment the anomalous behavior of $\rho(T)$ in magnetic field can be due to both a change in the magnetic properties of the $\alpha \mathrm{BiMn}$ phase below $100 \mathrm{~K}$ and the effect of magnetization on the electronic structure (the Fermi surface) of the bismuth phase.

Dependencies of the relative magnetoresistance $\Delta \rho / \rho_{0}=[((\rho(H)-\rho(H=0)) / \rho(H))] \times 100 \%$ on temperature for $\boldsymbol{H} \| \boldsymbol{I}$ and $\boldsymbol{H} \perp \boldsymbol{I}$ are shown in Fig. 5. In both cases the magnetoresistance increases with decreasing temperature (positive magnetoresistance) and goes to saturation below $100 \mathrm{~K}$. The saturation temperature $T_{\text {sat }}$ increases with increasing magnetic field and it is higher for the configuration $\boldsymbol{H} \| \boldsymbol{I}\left(T_{\text {sat }} \approx 45 \mathrm{~K}\right.$ and $T_{\text {sat }} \approx 62 \mathrm{~K}$ for fields of $800 \mathrm{kA} / \mathrm{m}$ and $2400 \mathrm{kA} / \mathrm{m}$, respectively) than for $\boldsymbol{H} \perp \boldsymbol{I}\left(T_{\text {sat }} \approx 21 \mathrm{~K}\right.$ and $T_{\text {sat }} \approx 50 \mathrm{~K}$ for the same fields). In different magnetic fields curves $\Delta \rho / \rho_{d}(T)$ are parallel for $\boldsymbol{H} \| \boldsymbol{I}$ and not parallel for $\boldsymbol{H} \perp \boldsymbol{I}$. It is interesting to note that in magnetic field of $2400 \mathrm{kA} / \mathrm{m} \Delta \rho / \rho_{0} \approx 250 \%$ for $\boldsymbol{H} \| \boldsymbol{I}$ and $\Delta \rho / \rho_{0} \approx 2400 \%$ for $\boldsymbol{H} \perp \boldsymbol{I}$. Difference in the $\rho(T)$ and $\Delta \rho / \rho_{d}(T)$ the behavior, as well as different $T_{\text {sat }}$ and $\Delta \rho / \rho_{0}$ values for $\boldsymbol{H} \| \boldsymbol{I}$ and $\boldsymbol{H} \perp \boldsymbol{I}$ indicate a strong anisotropy of the magnetotransport properties in our sample. We also have to note that the magnetoresistance of pure bismuth increases up to helium temperatures [11-13] and its magnitude is several orders higher than in our case.

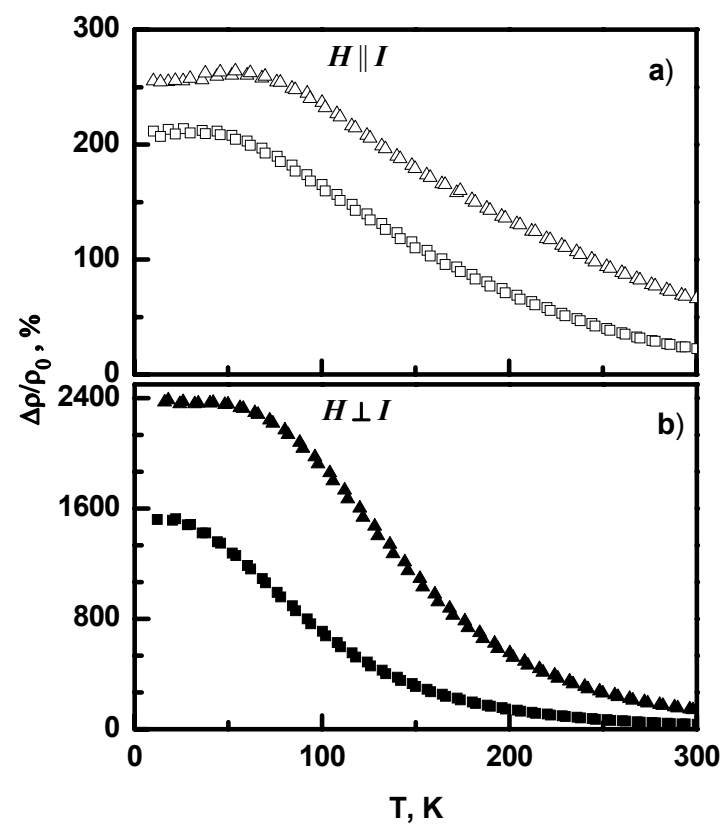

Fig. 5. The $\Delta \rho / \rho_{d}(T)$ curves in $\mathrm{Mn}_{3.69} \mathrm{Bi}_{95.69} \mathrm{Fe}_{0.62}$ for two orientations of the field ( $\square, \Delta-\boldsymbol{H} \| \boldsymbol{I}$, and $\mathbf{\square}, \boldsymbol{\Delta}-\mathbf{H} \perp \mathbf{I}$ ) in magnetic fields $800 \mathrm{kA} / \mathrm{m}(\boldsymbol{\square}, \square)$ and $2400 \mathrm{kA} / \mathrm{m}(\boldsymbol{\Delta}, \Delta)$.

According to modern representations, bismuth has a rather complex band structure. The Fermi surface consists of three highly elongated electron areas that are similar to ellipsoids and one hole ellipsoid of revolution [14, 15]. In order of magnitude, the Fermi energy is a few hundredth electron volts. As a result, any external perturbations (temperature, magnetic field, deformations, etc.) can easily affect the degree of overlapping of the electron and hole areas and, as a consequence, on the kinetic properties (the electrical conductivity in our case).

The superposition of electron and hole Fermi surfaces on each other leads to a metal-dielectric transition, and intermediate states are also possible. In Ref. [16 ] it is shown that phenomena similar to magnetic breakdown (quantum tunneling of charge carriers in a magnetic field between different energy bands) can be observed in bismuth even in relatively small fields (up to $2400 \mathrm{kA} / \mathrm{m}$ ) in measurements along the selected directions.

Change in the angle of inclination of the magnetic field relatively to the crystallographic directions of Bi as well as 
the change in the magnetization of $\alpha$ BiMn phase in our case can lead to a change in the shape of the Fermi surface and the degree of overlapping between the electron and hole regions. This can lead both to the deviation of the behavior of the electrical resistivity with respect to pure bismuth, and the appearance of a strong anisotropy of the temperature dependences of both, electric and magnetoresistance.

In conclusion, we note that in the near future it is planned to study the magnetic field dependences of the electrical resistivity and magnetization of $\mathrm{Mn}_{3.69} \mathrm{Bi}_{95.69} \mathrm{Fe}_{0.62}$ at different temperatures, which will allow us to explain in more detail the behavior of the electrical resistivity in magnetic field.

\section{CONCLUSIONS}

1. It was found that studied Bi-Mn solid solution has a composition of 95.69 at.\% Bi, 3.69 at.\% Mn and 0.62 at\% $\mathrm{Fe}$, and includes two phases, namely a bismuth matrix with $\alpha \mathrm{BiMn}$ inclusions. It is shown that the sample has a crystalline texture.

2. The revealed maximum at $T_{\max } \approx 85 \mathrm{~K}$ on the temperature dependences of the magnetization is associated with the reorientation transition of the magnetic moments of $\mathrm{Mn}$ which occurs in the $\alpha \mathrm{BiMn}$ phase and disappears in fields above $2400 \mathrm{kA} / \mathrm{m}$.

3. It is shown that the main contribution to the electrical conductivity of our sample is contributed by the bismuth phase.

4. It is established that the $\rho(T)$ dependence in the magnetic field differs radically from that observed in the absence of magnetic field. For $\boldsymbol{H} \perp \boldsymbol{I} \rho(\mathrm{T})$ increases with decreasing temperature, and reaches a maximum at $T_{\max } \approx$ $58 \mathrm{~K}$ when field is $800 \mathrm{kA} / \mathrm{m}$, and is shifted to higher temperature $T_{\max } \approx 94 \mathrm{~K}$ with increasing field up to $2400 \mathrm{kA} / \mathrm{m}$. At the same time no clear maximum on $\rho(T)$ is observed for $\boldsymbol{H} \| \boldsymbol{I}$.

5. It is shown that the magnetoresistance is positive in the entire temperature range from $300 \mathrm{~K}$ down to $4.2 \mathrm{~K}$ and noticeably increases with decreasing temperature but goes to saturation below $100 \mathrm{~K}$. The measured magnetoresistances is $\Delta \rho / \rho_{0} \approx 250 \%$ for $\boldsymbol{H} \| \boldsymbol{I}$ and $\Delta \rho / \rho_{0} \approx 2400 \%$ for $\boldsymbol{H} \perp \boldsymbol{I}$ in a magnetic field of $2400 \mathrm{kA} / \mathrm{m}$.

6. All results suggest a strong anisotropy of $\rho(T)$ and $\Delta \rho / \rho_{d}(T)$ observed for different field orientation, namely for $\boldsymbol{H} \perp \boldsymbol{I}$ and $\boldsymbol{H} \| \boldsymbol{I}$.

7. It is suggested that the anomalous behavior of the electrical resistivity in a magnetic field with respect to pure bismuth can be related to change in the shape of the Fermi surface and the degree of overlapping between its electron and hole regions. It is likely possible because of the change in the magnetization of $\alpha$ BiMn phase, which is believed to depend on magnetic field magnitude and its orientation.

\section{REFERENCES}

1. Yong-Sheng Liu, Jin-Cang Zhang, Zhong-Ming Ren, Min-An Gu, Jing-Jing Yang, Shi-Xum Cao, Zheng Long Yang Fabrication, Structural and Magnetic Properties for Aligned MnBi // Chin. Phys. Lett. - 2010. - Vol. 27. - P.097502-1 097502-4.

2. Rama Rao N.V., Gabay A.M., Hadjipanayis G.C. Anisotropic fully dense MnBi permanent magnet with high energy product and high coercivity at elevated temperatures // J. Phys. D: Appl. Phys. - 2013. - Vol. 46. - P.062001-1 - 062001-4.

3. Svetlov V.N., Terekhov A.V., Stepanov V.B., Solovjov A.L., Khristenko E.V., Ivasishin O.M., Shevchenko A.D., Kovalyuk Z.D. Anisotropy of resistivity in $\mathrm{Bi}_{93.99} \mathrm{Mn}_{6} \mathrm{Fe}_{0.01}$ // Low Temperature Physics. - 2015. - Vol.41. - No.4. P.314-317.

4. Oikawa Katsunari, Mitsui Yoshifuru, Koyama Keiichi, Anzai Koichi Thermodynamic Assessment of the Bi-Mn System // Materials Transactions. - 2011. - Vol.52. - No.11. - P.2032-2039.

5. Yin F., Gu N., Shigematsu T., Nakanishi N. Sintering formation of low temperature phase MnBi and its disordering in mechanical milling // J. Mater. Sci. Technol. - 1996. - Vol.12. - P.335-341.

6. Yang J.B., Yelon W.B., James W.J., Cai Q., Kornecki M., Roy S., Ali N., l'Heritier Ph. Crystal structure, magnetic properties and electronic structure of the MnBi intermetallic compound // J. Phys.: Condens. Matter. - 2002. - Vol.14. - P.6509-6519.

7. Shoenberg D., Uddin M.Z. The Magnetic Properties of Bismuth. I. Dependence of Susceptibility on Temperature and Addition of Other Elements // Proc. R. Soc. Lond. A. - 1936. - Vol.156. - P.687-701.

8. Focke A.B., Hill J.R. The Electrical Resistivity of Bismuth Single Crystals // Phys. Rev. - 1936. - Vol. 50. - P. $179-184$.

9. Kaye G.W.C. The Thermal and Electrical Resistance of Bismuth Single Crystals The Effects of Temperature and Magnetic Fields // Proceedings of the Royal Society of London. Series A, Mathematical and Physical Sciences. - 1939. - Vol. 170. No.943. - P. 561-583.

10. Thompson N. The Electrical Resistance of Bismuth Alloys // Proc. R. Soc. Lond. A. - 1936. - Vol.155. - No.884. - P.111-123.

11. Jewett F.B. The Effect of High Temperatures on the Change of Resistance of Bismuth in a Magnetic Field // Phys. Rev. (Series I). - 1903. - Vol. 16. - No.1. - P. 51-59.

12. Kapitza P. The Study of the Specific Resistance of Bismuth Crystals and Its Change in Strong Magnetic Fields and Some Allied Problems // Proc. R. Soc. Lond. A. - 1928. - Vol.119. - No.782. - P.358-443.

13. Alers P.B., Qebber R.T. The Magnetoresistance of Bismuth Crystals at Low Temperatures // Phys. Rev. - 1953. - Vol. 91. No.5. - P. 1060-1065.

14. Fal'kovskiî L.A. Physical properties of Bismuth // Sov. Phys. Usp. - 1968. - Vol. 11. - No.1. - P. 1-21.

15. Edel'man V.S. Properties of electrons in Bismuth // Sov. Phys. Usp. - 1977. - Vol. 20. - P. 819-835.

16. Bogod Yu.A., Eremenko E.E. Magnetoresistance of Bismuth in strong magnetic fields // JETP Letters. - 1966. - Vol.3. No.4. - P.113-115. 